\title{
Investigation of Biogas Energy Yield from Local Food Waste and Integration of Biogas Digester and Baking Stove for Injera Preparation: A Case Study in the University of Gondar Student Cafeteria
}

\author{
Ashenafi Tesfaye Bicks (iD) \\ Department of Mechanical Engineering, Institute of Technology/University of Gondar, Gondar, Ethiopia \\ Correspondence should be addressed to Ashenafi Tesfaye Bicks; ashenafites1234@gmail.com
}

Received 11 May 2020; Revised 3 August 2020; Accepted 17 August 2020; Published 30 August 2020

Academic Editor: Mohammad Khan

Copyright (C) 2020 Ashenafi Tesfaye. This is an open access article distributed under the Creative Commons Attribution License, which permits unrestricted use, distribution, and reproduction in any medium, provided the original work is properly cited.

\begin{abstract}
Energy shortage is the main problem while preparing food at the university in Ethiopia. Baking of injera consumes a lot of firewood due to the nature of baking mitad and layout of the system. The daily average firewood consumption is $8600 \mathrm{~kg}$ which is equivalent to $790.3 \mathrm{~m}^{3}$ of gas. In this study, an investigation of energy yield from food waste is examined by assessing the daily waste generation rate from the university student cafeteria and configuring the baking stove (mitad) that utilizes biogas energy. CFD is used to investigate the performance and heat distribution of baking mitad. In the study, the measured average daily biodegradable food waste and kitchen waste generation rate in the campus is around $863 \mathrm{~kg} /$ day. The conversion of this food waste using the anaerobic digestion system yields $43.2 \mathrm{~m}^{3}$ biogas per day. Utilizing the daily biogas generated for baking injera improves the overall food making process and reduces firewood consumption by $5.4 \%$. This biogas energy yield is considered to be utilized for baking injera in the kitchen. The designed biogas mitad (stove) does not generate smoke due to the type of fuel used and configuration of baking mitad. Furthermore, the stove has an insulation mechanism considered to conserve the heat loss to the surrounding. Generally, the utilization of the biogas system and integration of the biogas injera baking stove will improve the overall food processing mechanism in the university.
\end{abstract}

\section{Introduction}

In Ethiopia, injera is the main food source which is made from a teff powder. During the process, teff powder is mixed with hot water to create dough; then, the dough is allowed to ferment for days; usually, sourdough starter (yeast) will be added to facilitate fermentation. This fermentation process could take place for 2 to 3 days depending on the temperature of the environment. The injera is then ready to be baked into large flat surface called mitad. The dough is liquid enough to pour into the flat surface of the baking stove (mitad); the flat pancakes (injera) will have a smooth texture in the bottom side, the side that has direct contact with the stove (mitad); and the upper surface creates a porous-like profile called eye. The quality of injera is also characterized by the uniform porosity (eye) created on the upper surface of the injera [1]. This baking process is commonly made by a biomassoperated stove (i.e., three-stone fireplace and improved injera baking stoves), on a clay plate known as mitad. Injera baking using a three-stone fireplace as shown in Figure 1 is very inefficient and consumes a lot of firewood. Additionally, it creates a health problem such as lung cancer due to smoke generated. In this study, the injera baking process is designed to be made using a biogas stove specially designed to consume biogas fuel. The designed system generates no smoke, and its efficiency is improved due to the addition of the insulation system and different layout used.

The designed biogas stove is mainly comprised of an injector, burner, and gas/air mixing chamber as shown in Figure 2. Inside the air/gas mixing chamber, there is a nozzle 


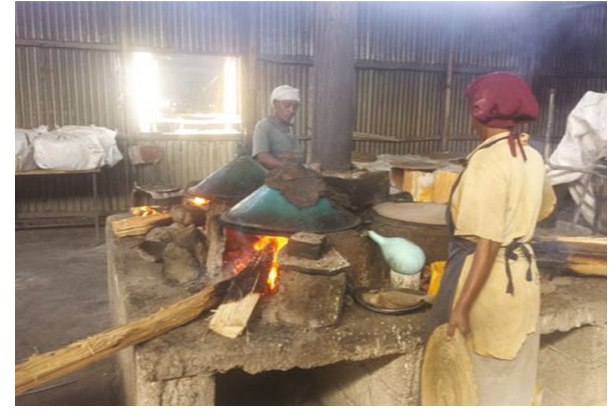

Figure 1: Atse Fasil Campus cafeteria kitchen while baking injera from firewood.

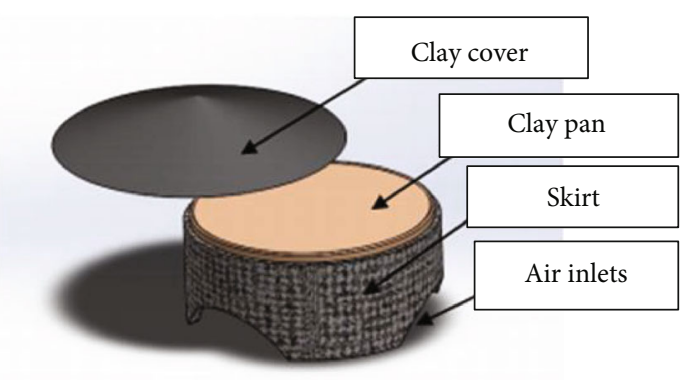

FIGURE 2: Biogas injera baking stove.

with an injector tapered into it as shown in Figure 3. Inside the burner head, the air/gas mixing chamber outlet is placed vertically to the surface of the burner head. The amount of air that enters the chamber maintains the combustion; it can be regulated by moving the injector into and out of the air/gas chamber, so the injector should be moved out of the air/gas mixing chamber to increase the rise of oxygen into it. The biogas injera baking stove has the same operating principle as a conventional biogas cookstove except for its size and insulation system. Its higher energy duty results in a considerably larger burner with a different configuration to have steady heat distribution throughout the claypan (mitad) [2]. Under this study, daily food waste that is dropped at the backyard of the university student cafeteria is used for biogas generation. Biogas is produced when anaerobic digestion of organic matter like food waste, kitchen waste, and other biodegradable waste is digested under anaerobic condition. Biogas mainly consists of methane and carbon dioxide with a small quantity of gas such as hydrogen. It is colorless but while cooking it has a blue burning flame [3]. The feed stoke used for conversion of biomass waste to biogas can be different depending on the availability of the waste at the local site, but the rate of methane yield depends on the property of the biomass type and digester type used [4].

Under this study, the integration of biogas stove/mitad with a biogas burner that utilizes biogas fuel for baking injera purpose is investigated. As a result, the overefficiency of the injera baking stove is measured as the ability of mitad (injera baking stove) to convert the energy from biogas (fuel) into energy gained by the baked injera. The burning efficiency of

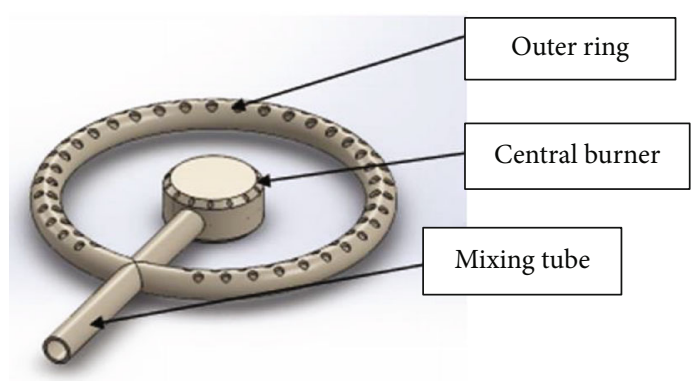

Figure 3: Biogas stove burner.

the stove is measured as the capacity of the stove to convert the energy from biogas fuel into heat energy [5].

\section{Assessment of Energy Usage: A Case Study in University of Gondar Student Cafeteria}

2.1. Energy Source Used for Baking and Cooking Application. In Ethiopia, a governmental university has to provide food throughout the year for their student enrolled regularly; injera and wot (traditional food that can be prepared from meat, grain, etc.) are the main source of meal consumed in a daily basis, doing so requires an enormous amount of energy per day. However, the kitchen tends to prepare the meal using firewood as the main energy resource as shown in Figure 1; burning the firewood beneath the traditional stove for cooking and baking is the main mechanism used as a preparation of food. Firewood is used as a source of energy for baking injera, and cooking is required around 2500 kuntal of wood every month; each kuntal of wood costs around 158 birrs without including transportation cost. Despite the high cost of buying the firewood, its main problem is deforestation leading to environmental effects as well as soil degradation. The smoke produced from the firewood in combustion in the cafeteria using a traditional threestone fireplace that lacks any provision for smoke exhaust exposes particularly women to smoke containing harmful products. Prolonged exposure to smoke is responsible for coughing, wheezing, acute respiratory infection, chronic obstructive lung disease, adverse pregnancy outcomes, and lung cancer [2].

2.2. Waste Generation and Removal System. In the campus, there are two major sources of waste: waste that comes from the student's food and waste that comes from the kitchen. The collected waste from the two main segments is dropped at the backyard of the kitchen as shown in Figure 4.

\section{Material and Methods}

3.1. Assessment of Waste and Collection from Kitchen and Student Cafeteria. The current number of students enrolled to use the Atse Fasil Campus cafeteria is around 3045; as a result, a huge amount of kitchen and food wastes is discharged daily. The appropriate amount of waste available and its type should be known before the design of the digester. Accordingly, collecting data has been made through 


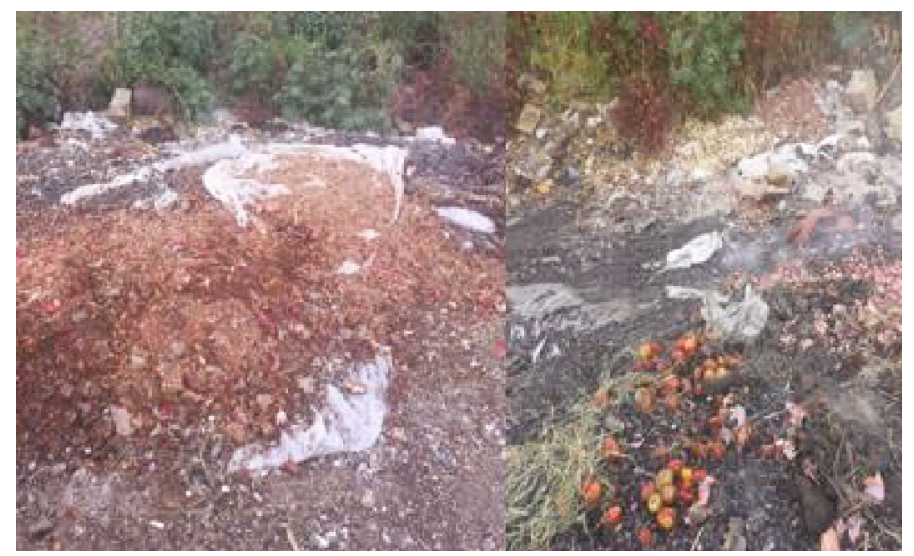

FIgURE 4: Food and kitchen waste removal in Atse Fasil Campus cafeteria.

TABLE 1: Type of solid wastes available and its description in the cafeteria.

\begin{tabular}{lcc}
\hline Number & Kinds of waste & Description \\
\hline 1 & Food waste & Food waste consists of fruit and food scrap obtained from a student after mealtime \\
2 & Kitchen waste & Kitchen waste consists of vegetable waste or peel obtained from the preparation of food \\
\hline
\end{tabular}

direct measurement of the waste using a balance at the disposal site. The solid wastes in the cafeteria are collected from two different segments as shown in Table 1.

3.1.1. Organic Solid Waste Data Collected. The maximum amount of solid organic waste obtained per day that contains both biodegradable and nonbiodegradable wastes from direct measurement using a balance is recorded as follows for only six days in 2019. The measurement was taken from two campuses as shown in Table 2 and Table 3.

\section{(1) Assumptions.}

(i) Consider $15 \%$ of kitchen waste is nonbiodegradable

(ii) Consider $95 \%$ of food waste is biodegradable

3.1.2. Daily Firewood Consumption for Cooking and Baking. The source of energy for cooking and baking is mainly consumed from firewood collected from the local forest by a contractor. Therefore, the firewood consumed for food preparation for 10 consecutive days is shown in Table 4 .

3.1.3. Analysis of Waste Obtained from Food and Kitchen. The data obtained from Tables 2 and 3 shows $95 \%$ of the food wastes are biodegradable and $85 \%$ of kitchen wastes are biodegradable. Therefore, the total mass of biodegradable waste can be calculated as follows:

(1) Total mass of food waste per day from two campuses $=765 \mathrm{~kg} /$ day

(2) Total mass of kitchen waste per day from two campuses $=160 \mathrm{~kg} /$ day

(3) The total mass of biodegradable food waste $=95 \%$ $* 765 \mathrm{~kg}=727 \mathrm{~kg} / \mathrm{day}$
(4) The total mass of biodegradable kitchen waste $=85$ $\% * 160=130 \mathrm{~kg} /$ day

(5) Then, the overall total mass of biodegradable waste $=727 \mathrm{~kg}+130 \mathrm{~kg}=863 \mathrm{~kg} /$ day

By using the total mass of biodegradable waste collected per day and property of waste type, the digester size and gas yield will be determined.

3.1.4. Biogas Energy Yield (Biogas Production from Food Waste). Biogas energy yield is found from the product of the overall total mass of biodegradable waste obtained per day and gas production rate from food waste found from physical property listed in Table 5.

The gas produced from food waste per day $=863 \mathrm{~kg} \times$ $0.05 \mathrm{~m}^{3} / \mathrm{kg}=43.2 \mathrm{~m}^{3} /$ day.

3.1.5. Daily Total Volumetric Flow Rate $\left(S_{d}\right)$ in Cubic Meter per Day.

$$
s_{\mathrm{d}}=\frac{\text { Total mass of biodegradable waste }}{\text { The density of food waste }} \text {. }
$$

Using Equation (1) and a physical property listed in Table 5, the daily total volumetric flow rate $\left(S_{\mathrm{d}}\right)$ is found to be $0.74 \mathrm{~m}^{3} /$ day. The fluid content in the waste is relatively good compared to other types of waste; as a result, applying a one-to-one dilution ratio to make the waste more mixable is important, so $0.74 \mathrm{~m}^{3} / \mathrm{d}$ of water is added. Therefore, the volume of the daily charge $\left(S_{\mathrm{d}}\right)$ is $1.48 \mathrm{~m}^{3} / \mathrm{d}$. Then, using the above daily flow rate, the size volume of the digester $\left(V_{\mathrm{D}}\right)$ will be determined which is defined as the product of the volume of the daily charge $\left(S_{\mathrm{d}}\right)$ and hydraulic retention 
TABLE 2: Recorded food waste per day for six consecutive days at campus 1 .

\begin{tabular}{lccc}
\hline No. & Date & Number of waste per bermill (barrel) & Remark \\
\hline 1 & $23 / 08 / 2019$ & 4 & \\
2 & $24 / 08 / 2019$ & 5 & \\
3 & $25 / 08 / 2019$ & 4 & Fasting \\
4 & $26 / 08 / 2019$ & 5 & \\
5 & $27 / 08 / 2019$ & 5 & Fasting \\
6 & $28 / 08 / 2019$ & 5 & \\
& & Average 4 &
\end{tabular}

Note: 1 bermill (barrel) $=85 \mathrm{~kg}$ (estimation). Then, amount of food waste $=4 * 85 \mathrm{~kg}=340 \mathrm{~kg} /$ day. Kitchen waste in Fasil Campus (campus 1) weights $80 \mathrm{~kg}$ per day.

TABLE 3: Recorded sample of food waste per day for six consecutive days at campus 2 .

\begin{tabular}{lcc}
\hline Number & Date & Number of waste per bermill (barrel) \\
\hline 1 & $23 / 08 / 2019$ & 6 \\
2 & $24 / 08 / 2019$ & 5 \\
3 & $25 / 08 / 2019$ & 5 \\
4 & $26 / 08 / 2019$ & 5 \\
5 & $27 / 08 / 2019$ & 6 \\
6 & $28 / 08 / 2019$ & 5 \\
& & Average $=5$
\end{tabular}

Note: the amount food waste $=5 * 85 \mathrm{~kg}=425 \mathrm{~kg} /$ day. Kitchen waste in Tewodros Campus (campus 2) weights $80 \mathrm{~kg}$ per day. Remark.

Table 4: Firewood used in Atse Fasil Campus per day for 10 consecutive days.

\begin{tabular}{lccr}
\hline No. & Date & Kuntal & Kilogram \\
\hline 1 & $21 / 08 / 2019$ & 82 & $8200 \mathrm{~kg}$ \\
2 & $22 / 08 / 2019$ & 84 & $8400 \mathrm{~kg}$ \\
3 & $23 / 08 / 2019$ & 81 & $8100 \mathrm{~kg}$ \\
4 & $24 / 08 / 2019$ & 88 & $8800 \mathrm{~kg}$ \\
5 & $25 / 08 / 2019$ & 89 & $8900 \mathrm{~kg}$ \\
6 & $26 / 08 / 2019$ & 84 & $8400 \mathrm{~kg}$ \\
7 & $27 / 08 / 2019$ & 80 & $8000 \mathrm{~kg}$ \\
8 & $28 / 08 / 2019$ & 82 & $8200 \mathrm{~kg}$ \\
9 & $29 / 08 / 2019$ & 81 & $8100 \mathrm{~kg}$ \\
10 & $30 / 08 / 2019$ & 85 & $8500 \mathrm{~kg}$ \\
& & Average $=84 \mathrm{kuntal} / \mathrm{day}$ \\
\hline
\end{tabular}

Note: $1 \mathrm{kuntal}=100 \mathrm{~kg}$. Therefore, the total amount of firewood consumed for baking and cooking in Atse Fasil Campus per day is $84 * 100 \mathrm{~kg}=8400$ $\mathrm{kg} /$ day.

time (HRT) [7]. Then, using Equation (2), the digester size is $36 \mathrm{~m}^{3}$ per day [8].

$$
V_{\mathrm{D}}=S_{\mathrm{d}} * \text { HRT } \text {. }
$$

3.1.6. Balancing Biogas Production and Energy Demand. The quantity, quality, and type of biomass available for
TABle 5: Basic information on the physical properties of the substances [6].

\begin{tabular}{lcc}
\hline No. & Type & Quantity \\
\hline 1 & Density of food waste & $1160 \mathrm{~kg} / \mathrm{m}^{3}$ \\
2 & Density of human waste & $1000 \mathrm{~kg} / \mathrm{m}^{3}$ \\
4 & Water content of the human manure & $90 \%$ \\
5 & Water content of urine & $94 \%$ \\
6 & Organic content of food waste & $85 \%$ \\
7 & Energy content of biogas & $38 \mathrm{MJ} / \mathrm{m}^{3}$ \\
8 & Gas production rate from human waste & $0.078 \mathrm{~m}^{3} / \mathrm{kg}$ \\
9 & Gas production rate from food waste & $0.05 \mathrm{~m}^{3} / \mathrm{kg}$ \\
10 & Retention time from food waste & $24 \mathrm{days}$ \\
\hline
\end{tabular}

TABLE 6: Various weight of dough measured at different times.

\begin{tabular}{lccc}
\hline Measurements & $\begin{array}{c}\text { Weight of dough } \\
(\mathrm{gm})\end{array}$ & 60\% water (gm) & 40\% teff (gm) \\
\hline 1 & $600 \mathrm{gm}$ & 360 & 240 \\
2 & $620 \mathrm{gm}$ & 372 & 248 \\
3 & $595 \mathrm{gm}$ & 357 & 238 \\
4 & $580 \mathrm{gm}$ & 348 & 232 \\
Average & $598 \mathrm{gm}$ & 359 & 240 \\
\hline
\end{tabular}

use in the biogas plant are the basic factor of biogas generation. The gas produced from food waste per day is the product of food waste per day and its gas production rate $[8]$.

3.1.7. Determining the Energy Demand. Determining biogas demand is based on present energy consumption, e.g., for ascertaining the baking energy demand. This involves either measuring or inquiring the present rate of energy consumption in the form of wood, charcoal, kerosene, and bottled gas, calculating biogas demand via comparable-use data.

3.1.8. Total Gas Required. The total energy consumption for cooking and heating purpose $\left(E_{\mathrm{c}}\right)=$ energy from firewood + energy from dung cakes + energy from charcoal + energy from LPG + energy from butane gas + energy from electricity [8].

Energy from firewood $=8300 \mathrm{~kg} /$ day; energy used for baking from firewood is $1 / 3$ of the total consumption used for making food which is around $2766 \mathrm{~kg} /$ day.

One cubic of biogas $=3.5 \mathrm{~kg}$ of firewood. Then, $1 \mathrm{~m}^{3}$ biogas $* 2766 \mathrm{~kg} / 3.5 \mathrm{~kg}=790.28 \mathrm{~m}^{3}$.

3.2. Analysis of Biogas Stove and Burner for Gas Produced. Under this study, a biogas burner is designed based on the maximum daily generation of gas from this plant. During the analysis, the data are collected through direct measurement and secondary data from GIZ; it expresses that the amount of water and teff in dough is $60 \%$ and $40 \%$, respectively. During the actual measurement, the weight of the dough measured has a slight variation in gram while baking injera as shown in Table 6 [8].

Based on the assessment made for injera baking, the average mass of the dough is around 598 grams per each injera 
baked. Estimation of energy demand for injera baking with dough $(Q)$ is found from the equation [9].

$$
Q=m \text { dough } \times C p, \operatorname{dough} \frac{T 2-T 1}{t} .
$$

3.2.1. Assessment of Biogas Flow Rate through a Stove Burner. The average power required for baking injera on mitad for a typical baking of mitad of $60 \mathrm{~cm}$ in diameter and efficiency of $25 \%$ is found from Equation (4) [9].

$$
p_{\text {required }}=\frac{p_{\text {out }}}{\text { efficency }} \text {. }
$$

Then, the output power from flame combustion required to bake injera is $5.696 \mathrm{~kW}$. Then, the biogas flow rate $\left(Q_{\mathrm{gas}}\right)$ is determined as follows:

$$
Q_{\text {gas }}=\frac{\text { energy needed }}{\text { calorific value }} \text {. }
$$

One volume of methane requires two volumes of oxygen, to give one volume of carbon dioxide and two volumes of steam. Since there is $58 \%$ methane in biogas and $21 \%$ oxygen in air, $1 / 0.58=1.72$ volume of biogas requires $2 / 0.21=9.52$ volume of air or one volume of biogas requires 9.52/1.72= 5.5 volume of air (stoichiometric air requirement). From the complete combustion process, the stoichiometric primary aeration required is 5.5; then, the entrainment ratio $r$ should be $r=5.5 / 2=2.75$ [10]. The mixture flow rate at optimum aeration is found from Equation (6) [5].

$$
Q_{m}=(1+r) 3600 .
$$

3.2.2. Pressure Drop in a Mixing Chamber. The pressure drop in the mixing tube, which should be at least $315 \mathrm{~mm}$ long $\left(15 \times d_{t}\right)$, can be calculated as follows:

$$
\Delta P=\frac{f}{2} \rho \frac{16 Q_{m}^{2}}{\pi^{2} \times d_{t}^{5}} .
$$

3.2.3. Burner Port Design. Burner port is at which the gas flows from it and burnt. It is more affected by high temperature, and the material selected for this purpose, stainless steel, resists a temperature of flame. So, using Equation (9), the area of the port is $0.00384 \mathrm{~m}^{2}$ [2].

$$
A p=\frac{Q_{m}}{0.25} .
$$

The number of ports required for efficient utilization of gas into mitad surface is found from Equation (9) [2].

$$
n p=\frac{4 A p}{\pi d_{p}^{2}} .
$$

TABLe 7: Dimension of the burner major component.

\begin{tabular}{lccc}
\hline No. & Component & Symbol & Value \\
\hline 1 & Orifice injector diameter & $d_{\mathrm{o}}$ & $3 \mathrm{~mm}$ \\
2 & Orifice channel length & $b$ & $4.5 \mathrm{~mm}$ \\
3 & Throat diameter & $(d t)$ & $18 \mathrm{~mm}$ \\
4 & Length of the mixing chamber & $(L)$ & $30 \mathrm{~mm}$ \\
5 & Length of air intake hole & $L_{\max }$ & $140 \mathrm{~mm}$ \\
6 & Diameter of the mixing chamber & $(D)$ & $26 \mathrm{~mm}$ \\
\hline
\end{tabular}

The analysis of the burner is conduced based on the maximum gas flow rate, and the geometrical setup for a major component of the burner is listed in Table 7.

3.2.4. Flame Height Determination. The main "combustion zone" is where the gas burns in the primary air and generates the heat in the flame. The "outer mantle" of the flame is where combustion is completed with the aid of the secondary air that is drawn into the flame from the sides.

The combustion products (carbon dioxide and steam) are at a high temperature, so rise vertically away from the flame, transferring heat to the air close to the top of the flame. It is this air moving vertically away that draws in the cooler secondary air to the base of the flame. The size of the inner cone depends on the primary aeration. A high proportion of primary air makes the flame much smaller and concentrated, giving higher flame temperatures [11].

The flame height $\left(L_{\mathrm{f}}\right)$ is related to the heat released $(Q)$ rate with the diameter of flame $D_{\mathrm{f}}$. The calculation of flame length is as follows:

$$
L=0.235 Q^{2 / 5}-1.02 D \text {. }
$$

\section{Result and Discussion}

4.1. Assessment and Sizing of a Biogas Digester Based on Available Waste. Among the various types of digesters, in this section of the design, fixed dome torispherical, a continuous feed (displacement) digester is selected for the reason that relatively small amounts of slurry (a mixture of manure and water) are added daily. This enables that gas and fertilizers are produced continuously and predictably. After selecting the type of digester, the retention time, which is a key parameter in determining digester size, is chosen to maximize the percentage of production of biogas with respect to the retention time. 24 days is chosen as the minimum amount of time for sufficient bacterial action to take place to produce biogas and to destroy many of the toxic pathogens found in human waste, considering the diameter $(d)$ and height $(h)$ of mixing pit are equal $(d=h)$. The geometry of the digester major components and mixing chamber shown in Table 8 is based on designation in Figure 5.

The mixing pit of the digester should have a size slightly greater than the daily input and better if no corners; therefore, by considering $10 \%$ factor of safety from daily input, the volume of the mixing pit is around $1.628 \mathrm{~m}^{3}$. 
TABLE 8: Digester component volume and diameter.

\begin{tabular}{lcc}
\hline Component & Symbol & Volume \\
\hline Mixing pit & $V$ & $1.628 \mathrm{~m}^{3}$ \\
Compensation tank & $V_{\text {tank }}=V 2$ & $8 \mathrm{~m}^{3}$ \\
Gas collecting chamber & $V_{\mathrm{c}}$ & $1.8 \mathrm{~m}^{3}$ \\
Gas storage chamber & $V_{\mathrm{gs}}$ & $18 \mathrm{~m}^{3}$ \\
Fermentation chamber & $V_{\mathrm{f}}=\mathrm{V} 3$ & $29.5 \mathrm{~m}^{3}$ \\
Volume of slurry & $V_{\mathrm{s}}$ & $6.5 \mathrm{~m}^{3}$ \\
\hline
\end{tabular}

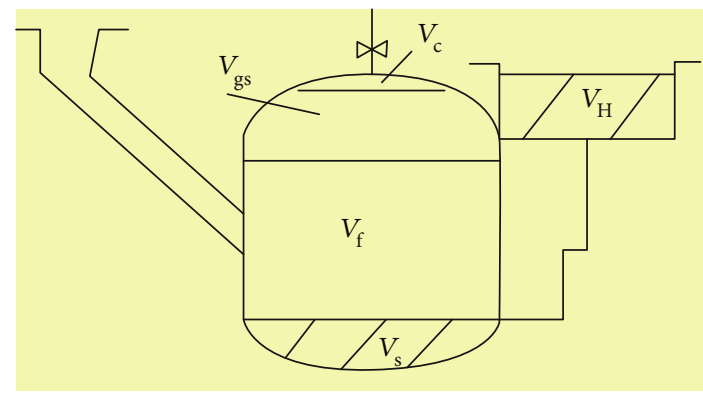

FIGURE 5: Biogas digester geometry configuration [2].

The dimension of the compensation tank $\left(V_{\text {tank }}\right)$ is around $20 \%$ of the digester (fermentation chamber and volume of slurry), and using Equation (11), it is found to be around $8 \mathrm{~m}^{3}$ [2].

$$
V_{\text {tank }}=0.20 * V D \text {. }
$$

In the analysis, for efficient spaces, the utilization cubic shape of the compensation tank is considered. For $36 \mathrm{~m}^{3}$ digester size, $8 \mathrm{~m}^{3}$ compensation tank is bigger in size but the daily feed stoke will increase following an increase in waste disposal resulted due to an increase in student number.

4.1.1. Pressure in the Gas Holder or Container. This maximum pressure is limited by the lower slurry level (LSL). When pressure increases to the point whereby the lower slurry level (LSL) is pushed down further below the beam/outlet pipe level, biogas will escape through the compensation chamber.

According to the analysis, the pressure inside the digester is $74.2 \mathrm{kPa}$. This is found from the assumption that the gas in the gas holder obeys the ideal gas law, i.e., $P V=n R T$; the molecular mass of the gas is $25.8\left(65 \% \mathrm{CH}_{4}\right.$ and $\left.35 \% \mathrm{CO}_{2}\right)$ and a density of $1.15 \mathrm{~kg} / \mathrm{m}^{3}$. The temperature of the gas is $301 \mathrm{~K}$ which is slightly higher than the ambient temperature [2]. The slurry is open to the atmosphere, and its pressure is equal to the atmospheric pressure of $101.1 \mathrm{kPa}$. As a result, the gas in the container will not escape from the gas holder since its pressure is lower than the pressure in the slurry.

4.1.2. Flow Rate of Gas from a Baking Stove Port. The average mass of the dough is around 598 grams per each injera baked. Using Equation (3) and property listed in Table 9, the energy
TABLE 9: Measured value for some property during the baking of injera.

\begin{tabular}{lcc}
\hline Property & Symbol & Value \\
\hline Specific heat of water at $100^{\circ} \mathrm{C}$ & $\mathrm{Cp} \mathrm{w}$ & $4.174 \mathrm{~kJ} / \mathrm{kg}{ }^{\circ} \mathrm{C}$ \\
Specific heat of teff at $100^{\circ} \mathrm{C}$ & $\mathrm{Cp} \mathrm{teff}$ & $1.046 \mathrm{~kJ} / \mathrm{kg}{ }^{\circ} \mathrm{C}$ \\
Combustion temperature & $\mathrm{T} 2$ & $126^{\circ} \mathrm{C}$ \\
Room/ambient temperature & $\mathrm{T} 1$ & $28^{\circ} \mathrm{C}$ \\
\hline
\end{tabular}

demand for baking injera is $1.424 \mathrm{~kW}$. The energy demand is calculated based on the actual measurement taken during the baking of injera in the cafeteria. It was also found that for an assessment made during baking, the average time required to make injera is 120 seconds, the mass of water is $0.359 \mathrm{~kg}$, and the mass of teff is $0.239 \mathrm{~kg}$, since the dough contains $60 \%$ of water and $40 \%$ of teff.

So, in order to attain the energy required by the baking stove which is $1.424 \mathrm{~kW}$, the biogas flow rate into the burner port has to be maintained at a rate of $0.93 \mathrm{~m}^{3} / \mathrm{hr}$, found from Equation (5). The size and shape of the injector orifice control the gas flow rate and hence heat input for a given gas composition and supply pressure. The sitting of the injector with respect to the mixing tube affects air entrainment, so the injector must be positioned with a high degree of precision.

In the analysis, maintaining the heat distribution at a rate of $1.424 \mathrm{~kW}$ will make the injera to be baked without changing its natural taste. The upper surface of the injera has to be rough and has a porous-like feature called eye, so this heat distribution will maintain the injera to create eye in the upper surface.

4.1.3. The Gas Pressure in the Throat. The gas pressure in the throat is $99 \mathrm{kPa}$, which is found from the parameter labeled in table and Equation (12).

$$
p_{t}=p_{o}-\rho \frac{v_{o}^{2}}{2 \times g}\left[1-\left(\frac{d_{o}}{d_{t}}\right)^{4}\right] \text {. }
$$

4.1.4. Pressure Drop in a Mixing Chamber. The pressure drop in the mixing tube, which should be at least $315 \mathrm{~mm}$ long $\left(15 \times d_{t}\right)$ [2], can be calculated as follows:

$$
\Delta P=\frac{f}{2} \rho \frac{16 Q_{m}^{2}}{\pi^{2} \times d_{t}^{5}} .
$$

The pressure drop due to the flow of the mixture in the mixing tube is checked, by first calculating the Reynolds number; then, the flow type is found to be laminar. In this study, the pressure drop is $2.57 \mathrm{~Pa}$ by considering the geometry shown in Figure 6; this pressure drop is much less than the pressure in the throat; thus, it is good to proceed.

4.1.5. Burner Port Design. If the diameter of the port is higher, there could be a problem in flame lift. Using $5 \mathrm{~mm}$ diameter holes to minimize the problem of flame lift, the total number of port found from Equation (9) is 195, as shown in Figure 6. 


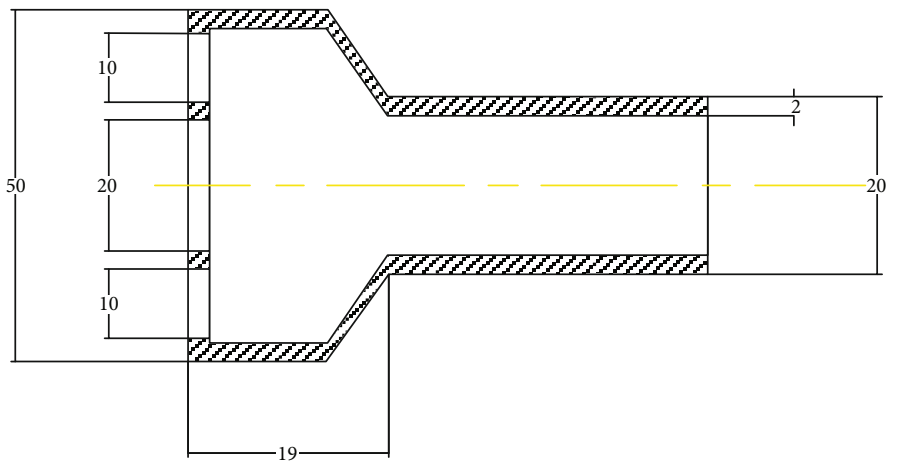

FIGURE 6: Mixing chamber geometry.

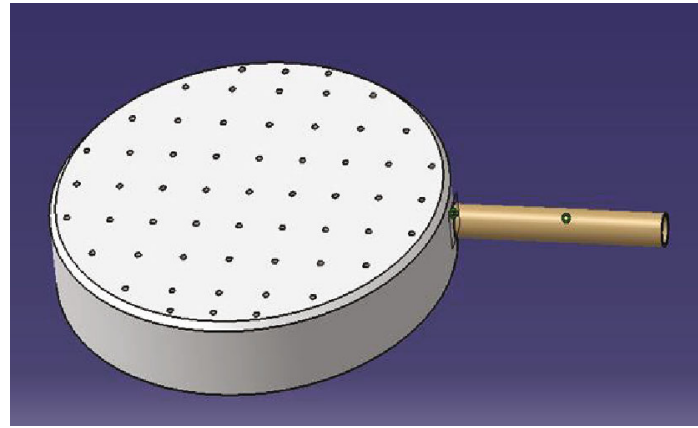

FIGURE 7: Burner port and gas/air inlet pipe.

Using the flame stabilization, it should be possible to reduce this number of burner ports by up to $1 / 3$, so 65 holes may be sufficient. The biogas stove does use 65 holes at $5 \mathrm{~mm}$ diameters (total burner port area $=12.96 \mathrm{~m}^{2}$ ) set at $90^{\circ}$ to the vertical, and the flames are fairly expanded on the left area. A larger burner port area would allow for greater flame stability [10].

Using 49 holes, with $10 \mathrm{~mm}$ gaps between holes, arranged in a circular pattern, gives a total circumference of $65(10+5)=975 \mathrm{~mm}$ as shown in Figure 7. The hole centers are then placed around a circle of diameter $310 \mathrm{~mm}$. Using more burner ports of the same diameter would mean a larger circle and a larger area over which the heat is distributed. This burner port size allows the biogas to flow into the baking mitad evenly. The shape of the burner port is critical for efficient utilization of the biogas fuel so the designed burner port is believed to discharge the fuel from the pipeline without loss.

4.1.6. Flame Stabilization from a Burner Port Outlet. The output power from flame combustion required to bake injera is $5.696 \mathrm{~kW}$. So, by assuming an even distribution of gas in all 65 ports, each port is expected to deliver heat at a rate of $0.087 \mathrm{~kW}$. Therefore, the length of the flame that passes through each hole is $82 \mathrm{~mm}$, found as in Equation (10) as shown in Figure 8.

4.1.7. Radiation Intensity and Shape Factor Determination between Burner and Mitad. The heat radiates from a burner of $20 \mathrm{~cm}$ to mitad of $60 \mathrm{~cm}$ diameter, and the space between them is the height of flame determined $82 \mathrm{~mm}$ as shown in

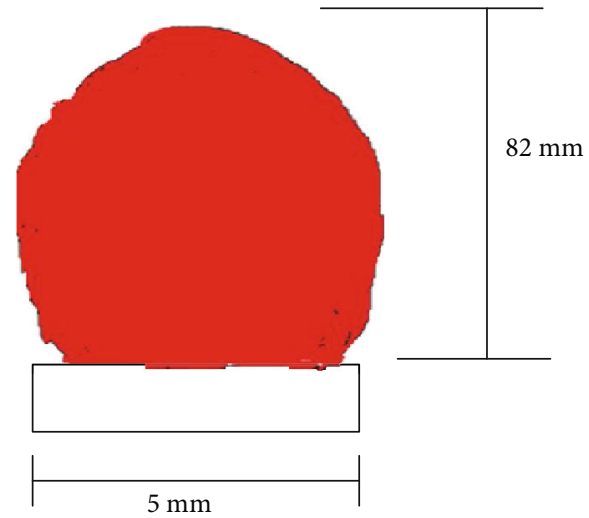

Figure 8: Flame height

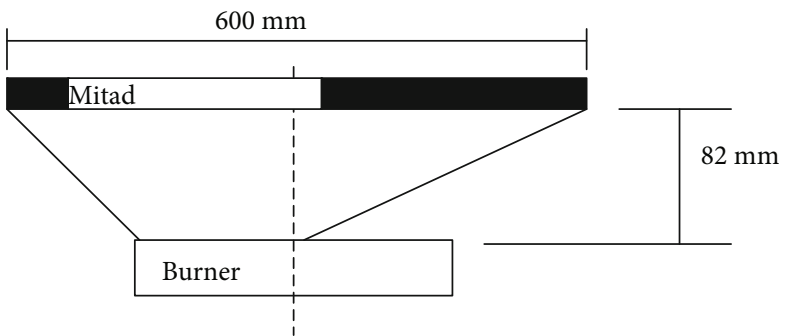

FIGURE 9: Heat transfer between burner and mitad by radiation.

Figure 9. The temperature inside the baking room is $35^{\circ} \mathrm{C}$ which is greater than the normal ambient temperature. Then, in order to reduce the rate of heat loss through the wall, an insulator with a wall radius of $0.35 \mathrm{~m}$ is considered. The heat flow through the wall is $Q=0.506 \mathrm{~kW}$, found from the following:

$$
\dot{Q}=\frac{800-T_{o}}{0.2+6.6 \ln \left(r_{3} / 0.301\right)+\left(0.11 / r_{3}\right)} .
$$

The intensity leaving the burner is $2.394 \times 10^{4} \mathrm{~W} / \mathrm{m}^{2}$, found from the following:

$$
I=\frac{\sigma T^{4}}{\pi}
$$




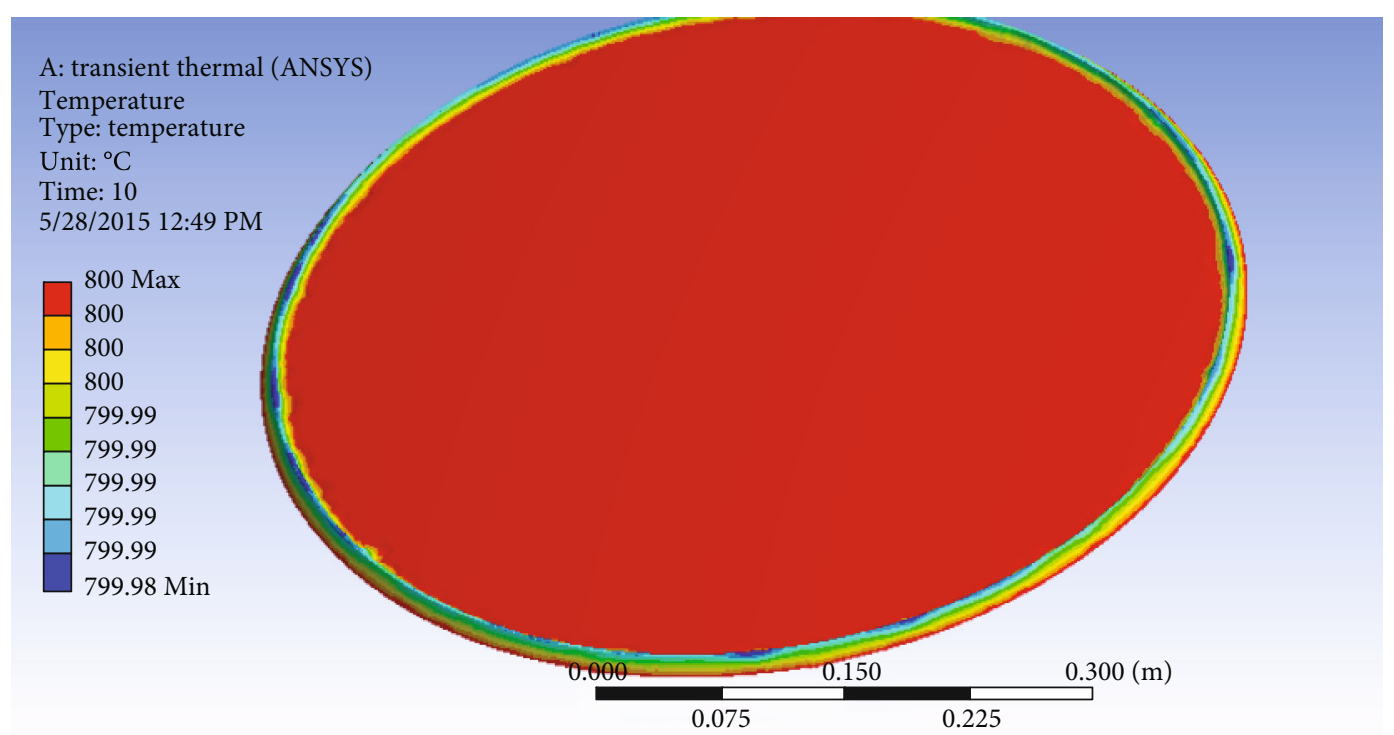

FIGURE 10: Transient thermal analyses over the mitad.

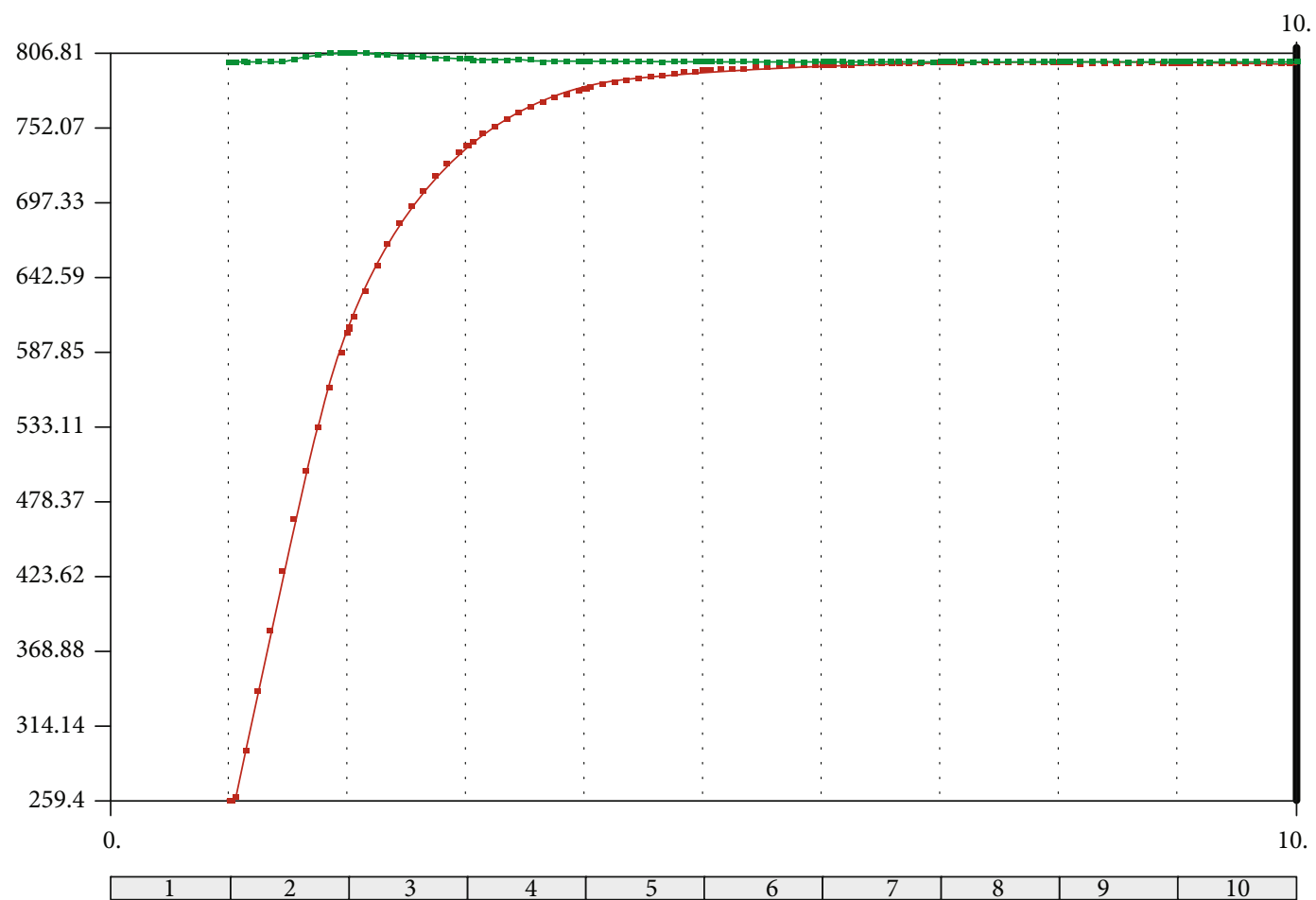

FIgURE 11: Overall temperature distribution over the mitad.

The shape factor is the heat flow through the stove per unit area of mitad; using Equation (16), it is found to be $1.79 \mathrm{~kW} / \mathrm{m}^{2}$.

$$
\text { Shape factor }=\frac{Q}{\text { area of mitad }} \text {. }
$$

In the analysis, maintaining the flame height at the indicated height beneath the baking stove creates required heat for the baking stove at the desired rate; this makes injera to be baked properly.

4.1.8. Temperature Distribution on Injera Baking Mitad. Using the value of intensity and shape factor, transient thermal analysis and heat distribution over the surface of the mitad are demonstrated. The distributions of heat over the mitad (baking stove) for 120 seconds are demonstrated shown in Figure 10. The temperature distribution over the 


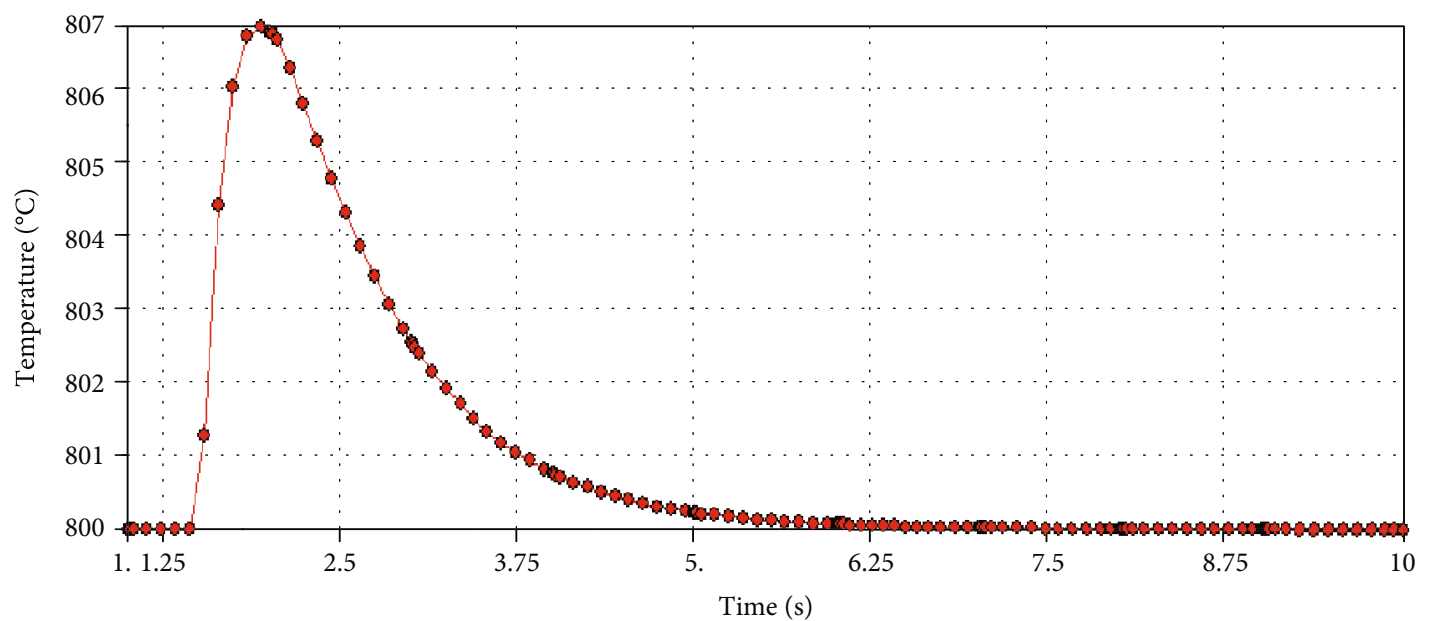

Figure 12: Global maximum temperature distribution over the mitad.

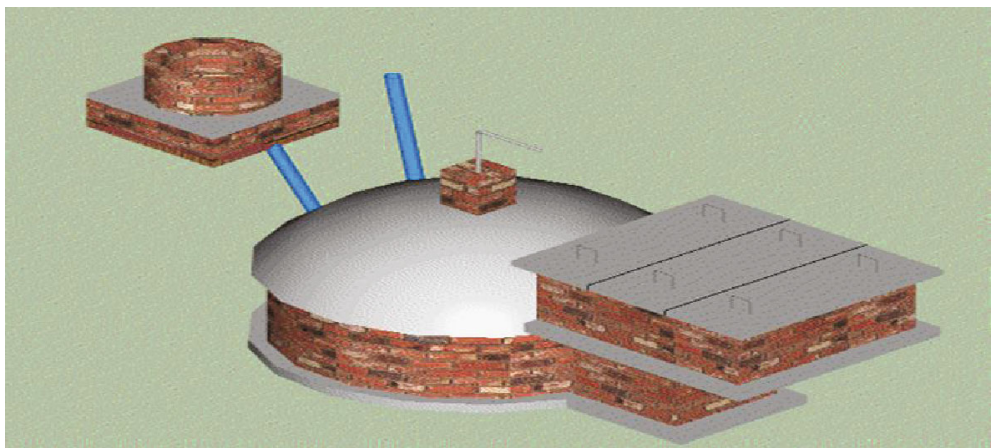

FIGURE 13: Biogas digester with a mixing pit and slurry outlet.

mitad is analyzed for 120 seconds which is the same as the actual measured value.

The simulated result in Figure 11 shows the heat distribution over the mitad under no baking condition. The heat radiates at a rate of $1.79 \mathrm{~kW} / \mathrm{m}^{2}$ to the bottom surface of $60 \mathrm{~cm}$ mitad. In the analysis, the temperature of mitad starts to raise to baking initial temperature of $294.4^{\circ} \mathrm{C}$ to maximum baking temperature of $806.8^{\circ} \mathrm{C}$. Baking mitad performance designed in this study has a similar operating system to that of an actual baking process except for their difference in fuel consumption type and layout.

When the dough is poured on the surface of the mitad, the temperature of the mitad starts to drop due to the fact that the baking mitad upper surface starts to absorb moisture from the wet dough. Then, after 5 seconds, the temperature of the baking mitad starts to flatten to a constant baking temperature of $800^{\circ} \mathrm{C}$, as shown in Figure 12. After a while, the heat from the mitad will absorb the moisture content fully from the dough and bottom surface of injera creating a dry and smooth profile.

4.1.9. Integration of a Biogas Digester and Burner Stove. Integration of a biogas digester to a baking stove is made by a pipe for the delivery of the methane gas to the end user. The type of pipe used for this system depends on the environ- mental condition of the site and location of the digester to the burner stove. However, PVC pipe and PPR pipe are the typical pipeline used for this system.

The gas will leave the digester at a pressure of $74.2 \mathrm{kPa}$ from the gas holder as shown in Figure 13. However, the designed pressure in the throat is $99 \mathrm{kPa}$, so a regulator is used to maintain the pressure to an optimum point.

According to the design in this study, the gas will be transported from the center of the dome as shown in Figure 13. Then, the gas will enter the burner through the pipe attached to the burner port as shown in Figure 14.

\section{Conclusion}

The demand for consumption of firewood during the injera baking process in the university cafeteria is very high due to the nature of the installed baking mechanism and the amount of injera baked. The daily average firewood consumption is $8600 \mathrm{~kg}$ which is equivalent to $790.3 \mathrm{~m}^{3}$ of gas on a daily basis. This amount of firewood consumption is the main cause of deforestation leading to drought in the country. The installed injera baking mechanism in the cafeteria is a traditional three-stone fireplace that lacks an energy conservation mechanism and smoke outlet. The exhaust smoke generated in the injera baking process exposes women to a 


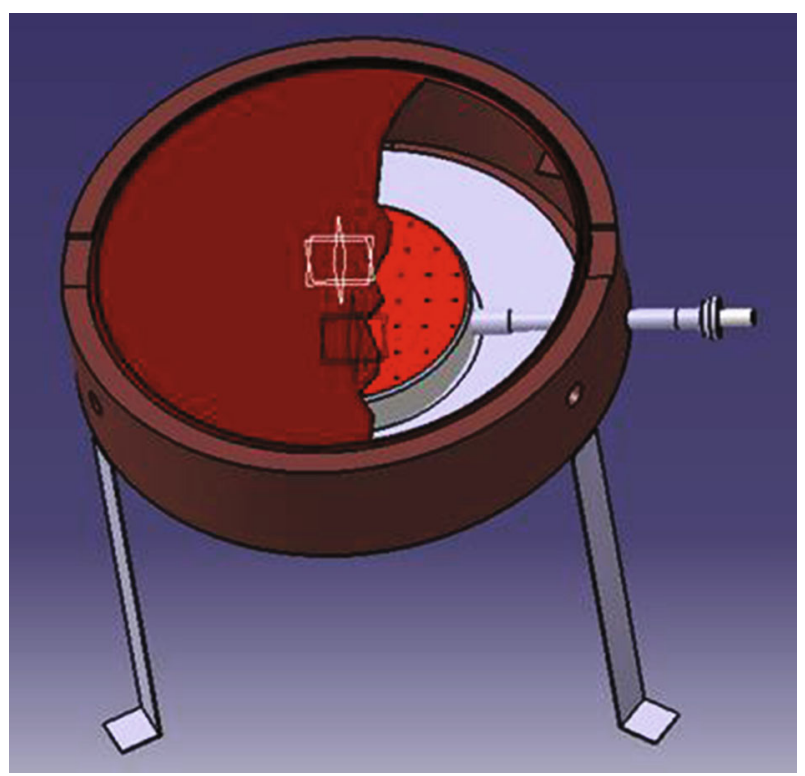

Figure 14: Biogas stove and burner.

serious health problem like lung cancer. So, to reduce the underlying issue stated, the biogas baking stove (mitad) is designed by integrating a biogas digester that yields methane from food waste.

In the study, the measured average daily biodegradable food waste and kitchen waste generation rate in the campus is around $863 \mathrm{~kg} / \mathrm{day}$; this kitchen and food wastes are disposed at the backyard of the cafeteria. The conversion of this food waste using the anaerobic digestion system yields $43.2 \mathrm{~m}^{3}$ biogas per day. Utilizing the daily biogas generated for baking injera improves the overall food making process and reduces all the firewood consumption by $5.4 \%$. In the study, a typical baking of mitad of $60 \mathrm{~cm}$ in diameter and efficiency of $25 \%$ requires an energy of $1.424 \mathrm{~kW}$. The average mass of the dough is around 598 grams per each injera baked. An assessment made during baking states that the average time required to make injera is 120 seconds. The baking stove requires the energy of $1.424 \mathrm{~kW}$; to maintain the energy demand required by the baking mitad, the biogas flow rate into the burner port is maintained at a rate of $0.93 \mathrm{~m}^{3} / \mathrm{hr}$. The biogas stove has 65 holes with $5 \mathrm{~mm}$ diameters opening adjusted at $90^{\circ}$ to the vertical position which creates greater flame stability. The heat input for a given gas composition and supply pressure to the mitad is controlled by injector orifice. The designed biogas stove has no smoke generated due to the type of fuel used and configuration of baking mitad (stove). Furthermore, the stove has an insulation mechanism considered to conserve the heat loss to the surrounding. Generally, the utilization of the biogas system and integration of the biogas injera baking stove will improve the overall food processing mechanism in the university. A modification in burner port design could also improve the overall performance of the baking system by allowing a free discharge of fuel which still remains to be investigated in the future. However, the utilization of additional food waste from other cafeterias in the university will increase biogas generation and reduce firewood consumption in the country.

\section{Data Availability}

The data sets supporting the conclusion of this article are included within the article.

\section{Conflicts of Interest}

The authors declare that they have no competing interests.

\section{Acknowledgments}

I would like to thank all my colleague for sharing their knowledge. I thank all Atse Fasil student cafeteria and Tewodros student cafeteria administrative staff for their continuous support during data collection. Last but not the least, I would like to thank the technology institute official for their support in giving a piece of information regarding cafeteria energy consumption data.

\section{References}

[1] K. D. Adem, D. A. Ambie, M. P. Arnavat, U. B. Henriksen, J. Ahrenfeldt, and T. P. Thomsen, "First injera baking biomass gasifier stove to reduce indoor air pollution, and fuel use," 2019, https://www.aimspress.com/fileOther/PDF/energy/ energy-07-02-227.pdf.

[2] D. Kebede and A. Kiflu, "Design of biogas stove for injera baking application by GIZ and SNV non-governmental organization," International Journal of Novel Research in Engineering and Science, vol. 1, no. 1, pp. 6-21, 2014.

[3] K. Rajendran, S. Aslanzadeh, and M. J. Taherzadeh, "Household biogas digesters-a review," Energies, vol. 5, no. 8, pp. 2911-2942, 2012.

[4] G. Lissens, ,W. Verstraete, ,T. Albrecht,,,,, et al., "Advanced anaerobic bioconversion of lignocellulosic waste for bioregenerative life support following thermal water treatment and biodegradation by Fibrobacter Succinogenes," Biodegradation, vol. 15, no. 3, pp. 173-183, 2004.

[5] J. R. Surange, N. K. Patil, and ,A. V. Rajput, "Performance analysis of burners used in LPG cooking stove-a review," International Journal of Innovative Research in Science, Engineering and Technology, vol. 3, no. 4, 2014.

[6] J. Gregory, S. Silveira, A. Derrick, P. Cowley, C. Allinson, and O. Paish, Financing Renewable Energy Projects, A Guide for Development Works, Intermediate Technology Publications in Association with the Stockholm Environment Institute, 1997.

[7] S. Singh, ,S. Kumar, M. C. Jain, and D. Kumar, "Increased biogas production using microbial stimulants," Bioresource Technology, vol. 78, no. 3, pp. 313-316, 2001.

[8] M. Asmare, "Design of cylindrical fixed dome bio digester in the condominium houses for cooking purpose at Dibiza site, East Gojjam, Ethiopia," American Journal of Energy Engineering, vol. 2, no. 1, 2014.

[9] A. Nigatu and B. A. Gashe, "Effect of heat treatment on the antimicrobial properties of tef dough, injera, kocho and aradisame and the fate of selected pathogens," World Journal of Microbiology and Biotechnology, vol. 14, no. 1, pp. 63-69, 1997. 
[10] J. W. Kang, C. M. Jeong, N. J. Kim, M. I. Kim, and H. N. Chang, "On-site removal of $\mathrm{H}_{2} \mathrm{~S}$ from biogas produced by food waste using an aerobic sludge biofilter for steam reforming processing," Biotechnology and Bioprocess Engineering, vol. 15, no. 3, pp. 505-511, 2010.

[11] Z. Ziauddin and P. Rajesh, "Production and analysis of biogas from kitchen wastevol. 2, no. 4, July 2015, https://www.irjet .net/archives/V2/i4/Irjet-v2i4109.pdf. 